\title{
IMPACT OF LOCUS OF CONTROL ON INVESTMENT BEHAVIOUR: A SEGMENTATION APPROACH
}

\author{
Fiona Sheenu Francis ${ }^{1}$, Dr.V Ambilikumar ${ }^{2}$ \\ ${ }^{1}$ Research Scholar, School of Management and Entrepreneurship, Kerala University of Fisheries and Ocean studies, Panangad, \\ Kerala \\ 2Professor, School of Management and Entrepreneurship, Kerala University of Fisheries and Ocean Studies, Panangad, Kerala. \\ Email id: ${ }^{1}$ fionasheenufrancis@gmail.com, ${ }^{2}$ ambilikumar@gmail.com
}

\begin{abstract}
Investment plays a vital role in a developing country such as India, as it provides the necessary funds for undertaking productive activities to be circulated in the economy. Savings are our country's largest source of investment. Investments are subject to the individual's attitudes, beliefs and perceptions. As a result, the attitudes and expectations of investors have a major impact on their investment behaviour. Locus of Control is one of the most important factors that affect individual's decision-making behaviour. Locus of Control is people's assumptions about what causes their lives to have good and bad outcomes (Rotter, 1966). It is said that there is internal and external LOC. Individuals with internal LOC assume they control their own destiny, whereas individuals with external LOC relate their experiences to destiny, luck or chance. Consequently, LOC has a great influence on an individual's investment decision-making behaviour. As a result, this study attempts to assess the LOC of an individual investors, segment them based on their level of internal and external LOC, and also to understand the impact of locus of control on the savings and investment behaviour of individual investors. The study revealed that most of the investors in Kerala were moderates and the locus of control of an individual investor affected their savings and investment behaviour
\end{abstract}

Keywords: Locus of control, Savings behaviour, Investment behaviour, Individual investor, Decision making behaviour.

\section{Introduction}

"If I have the belief that I can do it, I shall surely acquire the capacity to do it even if I may not have it at the beginning." -Mahatma Gandhi

Policymakers world over have enormously considered the savings rates of households, asset portfolios and level of wealth as priority target for national policy interventions (Cobb- Clark et.al, 2016). India, being a fast-growing economy in the world, has undergone several changes in its financial setup since its independence and is also constantly undergoing economic reforms with the objective to attain a financially inclusive India by 2022 and a $\$ 5$ trillion economy by 2024-25(Economic survey 2018-19). These reforms and changes in the financial sector have increased the complexities of decision making and risk attributes for individual investors. Moreover, investors have differing thought processes, while making investment decisions. Each and every person wants to invest their savings in the safest and secure avenue. The decisions, however, varies for each individual, and his ability to take the risk.

Investment behaviour is linked to individual investor activities related to searching, analysing, obtaining, evaluating the financial products and safely dispose of such investment products, if essential (Kasilingam and Sudha,2010). Investment behaviour is defined as how the investors surmise, forecast, interpret and evaluate decision-making processes, which include investment psychology, information gathering, identifying, comprehending, and research analysis. This whole procedure is investment behaviour (Solvic, 1972). These behaviours of investors are affected by their psychological set up.

Psychologists and other social scientist have made significant strides in discovering how individuals and group actions and the workings of the cortex influence individual choices. Financial analyst and researchers throughout history have acknowledged the effect of human psychology on financial decision-making and economic outcomes (Baker and Ricciardi,2014). More noteworthy is the incorporation of 'temptation' and 'self-control' into the economic models of inter- temporal decision-making, in the field of savings and investment decisions (Thaler and Shefrin,1981; Shefrin and Thaler,1988). These behavioural decision- making models are mainly based on the bounded rationality theory of Simon. Simon's (1978) theory of bounded rationality evokes the perspective that optimal decision-making is cramped because of cognitive impediments and information accessibility (Simon, 1990). 
The main aim of this paper is to contribute to this emerging field of behavioural research by empirically evaluating the linkage between locus of control and individual investment behaviour. Since locus of control is one of the most researched psychological concepts (Rotter,1990) it indicates that it exerts a great impact on how an individual makes his/her choices whether it may be in the case of investing or in any other field. The psychological concept of locus of control has developed more than 50 years ago from the framework of Rotter's 1954 Social learning theory of personality. Locus of control seizes "whether or not the person perceives a causal relationship between his own behaviour and the reward" (Rotter, 1966, p. 1). Gebhart and Schmidt (2013) in the Encyclopaedia of pain defines Locus of control as "Beliefs about whether certain outcomes in life are a result of one's efforts (internal) or a result of luck, fate, or the actions of others (external)". A person with a high (also recognized as an internal) locus of control assumes that outcomes in life are the results of one's own actions and behaviours. On the contrary, a person with a lower (or external) locus of control assumes that life outcomes are beyond one's control but are the consequences of external influences such as fate, chance, luck and other individuals (Heckman et al., 2006; Cobb-Clark and Tan, 2011; Cobb-Clark and Schurer, 2013).

Prior studies have revealed that locus of control can justify the motivation, decisions, behaviour and personal objectives of an individual. More explicitly, people with a considerably higher locus of control tend to show stronger initiative, motivation, and productivity, and thus tend to become more successful in general (Linz and Semykina, 2007). In addition, the locus of control may have significant consequences for the individual's possibility of jobs in occupations such as those of executives, scientists, and engineers (Cobb-Clark and Tan, 2011). It can also serve as a psychological shield against several stressful life events that individuals may encounter (Buddelmeyer and Powdthavee, 2016). Besides these advantages, there is also proof that locus of control is linked to risk behaviours. Heckman et al. (2006) suggest that the locus of control plays a prominent role in understanding risky behaviours of adolescents and young adults, including daily smoking, drug use, crime activity, and imprisonment. Cobb-Clark et al. (2016) demonstrates that humans with a higher locus of control appear to save more. Psychologists claim that a primary element of self-control (Rosenbaum, 1980) and motivation (i.e., effort) (Bandura, 1989; Skinner, 1996) is the belief of a person that his or her conduct will result in the intended result. Therefore, control expectations are central to recognizing the ability of individuals to resist immediate temptation and to attain their long-term objectives.

\section{Review of literature:}

Locus of control is a psychological construct that originated over 50 years ago from social learning theory. "A generalised attitude, perception, or expectancy about the existence of the causal relationship between one's own actions and its consequences" (Rotter, 1966, p.2). According to Rotter (1966), when a reinforcement is viewed by the subject as... not entirely dependent upon his decision, it is usually perceived as the product of luck, circumstance, destiny, as under the sway of powerful others, or as unforeseen because of the great complexity of the forces surrounding him. When a person interprets an experience in this manner, we refer to it as a belief in external control. We call this a belief in internal control when an individual believes that the outcome is determined by his own actions or reasonably stable characteristics (p. 1). Locus of control is the present-day idiom for the notion of internal versus external control of reinforcement which has evolved from the Rotter's (1954) social learning theory. It was originally developed by Julian B. Rotter in the 1950's. Locus of control is an inner feeling that people possess regarding the extent to which they are proficient of making their own decisions and viewing the outcomes as coming from those decisions (Inoue, 2013). The word locus has derived from Latin meaning location or place. If an individual believes that he/she is in control of their lives, there exists locus internally. If an individual believes that fate, luck, other people, environment or higher authority control their lives, there exists locus externally. Locus of control is a personality variable, which has its roots in the social learning theory developed by Rotter in 1954 (Saboe and Spector, 2015). Social learning theory integrates learning theory with personality theory, which is one of the seminal works on clinical psychology. The premise of the theory is that a person's actions are anticipated on the basis of the person's expectations of reinforcement, the perceived value of the reinforcement, and the circumstances in which the person finds himself or herself (Kormanik and Rocco, 2009).

Rotter's motivating factor was the empirical law of effect. People are encouraged to seek out constructive stimuli, or reinforcement, and to resist negative stimulus, according to the law of effect. Rotter combined behaviourism and personality research without relying on physiological drives or impulses as a motivating force. Julian Rotter's social learning theory's core premise is that personality is the product of an individual's interaction with his or her environment. Rotter assumes that personality, and therefore behaviour, is still malleable. Adjust the way a person feels or the environment in which they are reacting, and their actions can change. Furthermore, during the 1960s, when the behaviourist approach was competing with the growing emphasis on cognitive psychology, the locus of control concept was developed as a way for social learning theorists to combine behavioural and cognitive theories (Rotter, 1975). They used locus of control to explain how certain control cognitions influence behaviour change. Around the same time, psychologists were turning their attention away from 
definitions of stable personality traits and toward behaviour modification. One idea that sought to overcome this void was locus of control, which used a human trait to model behaviour change (Lefcourt, 1992).

Social learning theory developed by Rotter has basically, 3 constructs to predict behaviour. They are; behavioural potential, expectancy and reinforcement value (Rotter, 1954). The probability of any behaviour resulting in a given situation is determined by the individual's expectation that the behaviour will secure the available reinforcement, as well as the importance of the available reinforcement for that person (Lefcourt, 1966). Reinforcement boots the likelihood that a specific behaviour or occurrence will be accompanied by reinforcement in future (Rotter, 1966). Expectancy is equivalent to the value of the reinforcement (Lefcourt, 1976). Expectancy entails that the person regard the result, possess self-efficacy, comprehend and believe the reward system, and eliminate unfavorable outcomes (Lawler, 1973). The chance of engaging in a particular behaviour in a given situation is known as behaviour potential. In other terms, what is the likelihood that a person will behave in a certain way in a given circumstance? In any given scenario, one may engage in a variety of behaviours. There is a behaviour potential for every possible behaviour. As a result the function of all these 3 constructs, helps us in the measurement and prediction of behaviour.

Since the introduction of locus of control theory, there has been enormous hike in research applying locus of control concept, and it has picked up widely in psychological as well as other fields of research ever since then (Mark, 1998). According to psychologists, an individual's expectation that his or her decisions can contribute to the desired outcome is a primary factor of both self-control (Rosenbaum, 1980) and motivation (i.e. effort) (Bandura, 1989; Skinner, 1996; Goldsmith et al., 2000). As a result, recognising individuals' desire to resist acute temptation and accomplish long-term goals is dependent on their perceptions of control. Selfmastery (i.e. locus of control) is one aspect of self-control, according to Rosenbaum (1980), who claims that 'before an individual applies some particular self-controlling ability, he must assume that he can control his own actions without outside assistance'. Locus of control is linked to the Big-Five elements of neuroticism and emotional stability, despite not being officially included in the taxonomy (Almlund et al., 2011). Given this, it's no surprise that a growing body of research connects locus of control to a variety of economic outcomes, including wages, unemployment, career quest, occupational preference, educational achievement, and life satisfaction (Cobb-Clark et al., 2014 \& Cobb-Clark, 2015, Cobb - Clark et al., 2016). More patience and a greater desire to take chances are often linked to cognitive abilities such as locus of control (Dohmen et al., 2010). Also, after accounting for education, the tendency to keep risky assets rises with numeracy, auditory fluency, memory, and IQ (Christelis et al., 2010 \& Grinblatt et al., 2011). It has been found that locus of control is related to risk taking behaviours of individuals. People with a higher locus of control save more, according to Cobb-Clark et al. (2016). Salamanca et al. (2016) examine how household heads' investment decisions are related to their 'economic' locus of control using data from the Dutch Central Bank Household Survey (DHS). They show that people with a higher economic locus of control are more likely to buy risky assets (such as mutual funds and stocks) and to keep a higher proportion of risky investments than people with a lower economic locus of control.

\section{Development of locus of control scale:}

Phares (1957) was the first to use a Likert style scale to quantify individual variations in locus of control, using 13 "external" attitudes and a similar number of "internal" attitudes. He hypothesized that participants who endorsed the internal, skill- related items would notice expectancy shifts similar to those seen with skill guidance. Subjects who chose external or chance-related objects were expected to behave in the opposite way. Although the evidence did not support this theory, the predictions derived from the 13 external items came close to statistical significance. Externally oriented subjects exhibited more unusual changes in expectancy than those with internal oriented attitudes. According to Rotter, James used Phares' results as the basis for his doctoral dissertation in 1957. He updated the most effective of the original items and inserted filler items, to conceal the test's intent. This is currently known as the James-Phares Scale 1957. James hypothesised that externals would behave similarly regardless of whether they were in a chance-bound or skill-bound category. He discovered low, but meaningful, associations between test scores and task conduct. External subjects' achievement and loss showed lower increments and decrements and they generalised less from task to task than internals, whose performance matched the skill instruction state (Rotter, 1966, p- 9). Using an extrasensory perception (ESP) mission, James and Rotter (1958) investigated the dimension of extinction of verbal expectancies. In this regard, they discovered that chance-bound groups differed significantly from skill-bound groups. However, systematic and detailed research results following Rotter, Seeman, Liverant, and Crowne's work were published during the early 1960s. Since then, a number of studies have been done to study the locus of control concept and to develop LOC scales for various specific areas and dimensions. Furnham \& Steele (1993) seeks a critical analysis of the multitude of unidimensional or sphere-specific locus of control measures that have been developed in the last 25 years. A table summarizing the various LOC scales developed is illustrated below. 
Table 1. Locus of Control Scales

\begin{tabular}{|c|c|c|c|c|c|}
\hline $\begin{array}{l}\text { Sl. } \\
\text { No. }\end{array}$ & Author & Year & Scale & No. of Items & Response scale \\
\hline \multicolumn{6}{|c|}{ General Locus of Control } \\
\hline 1. & Phares & 1957 & $\begin{array}{l}\text { Phares Internal-External Locus of } \\
\text { Control Scale }\end{array}$ & 26 & $\begin{array}{l}\text { Likert style } \\
\text { scale }\end{array}$ \\
\hline 2. & James & 1957 & $\begin{array}{l}\text { James Internal-External Locus of } \\
\text { Control Scale }\end{array}$ & 60 & $\begin{array}{l}\text { Three-point } \\
\text { Likert scale }\end{array}$ \\
\hline 3. & Rotter & 1966 & $\begin{array}{l}\text { Rotter Internal-External Locus of } \\
\text { Control Scale }\end{array}$ & 23 & Forced choice \\
\hline 4. & Levenson & 1974 & Levenson IPC Scale & 24 & $\begin{array}{l}\text { Seven-point } \\
\text { Likert } \\
\text { scale }\end{array}$ \\
\hline 5. & Reid \& Ware & 1974 & $\begin{array}{l}\text { Reid-Ware Three-Factor Internal- } \\
\text { External Scale }\end{array}$ & 45 & $\begin{array}{l}\text { Seven-point } \\
\text { Agree -disagree }\end{array}$ \\
\hline 6. & Lefcourt & 1981 & $\begin{array}{l}\text { Multidimensional Multi- } \\
\text { attributional Causality Scale }\end{array}$ & 48 & $\begin{array}{l}\text { Five- point } \\
\text { Likert scale }\end{array}$ \\
\hline 7. & $\begin{array}{l}\text { Paulhus } \quad \& \\
\text { Christie }\end{array}$ & 1981 & Spheres of Control & 30 & $\begin{array}{l}\text { Seven-point } \\
\text { Likert scale }\end{array}$ \\
\hline 8. & Duttweiler & 1984 & Internal control index & 28 & $\begin{array}{l}\text { Five-point } \\
\text { agree- disagree }\end{array}$ \\
\hline \multicolumn{6}{|c|}{ Age related Locus of Control } \\
\hline 9. & Bialer & 1961 & $\begin{array}{l}\text { Bialer-Cromwell Children's } \\
\text { Locus of Control Scale }\end{array}$ & 23 & Yes/No \\
\hline 10. & Battle \& Rotter & 1963 & $\begin{array}{l}\text { Children's Picture Test for I-E } \\
\text { Control }\end{array}$ & 6 cartoons & $\begin{array}{l}\text { Seven-point } \\
\text { rating }\end{array}$ \\
\hline 11. & $\begin{array}{l}\text { Crandall, } \\
\text { Katkovsky and } \\
\text { Crandall }\end{array}$ & 1965 & $\begin{array}{lr}\text { Crandall } & \text { Intellectual } \\
\text { Achievement } & \text { Responsibility } \\
\text { Questionnaire } & \end{array}$ & 34 & Forced-choice \\
\hline 12. & $\begin{array}{l}\text { Nowicki } \quad \& \\
\text { Strickland }\end{array}$ & 1973 & $\begin{array}{l}\text { Nowicki-Strickland Locus of } \\
\text { Control Scale for children }\end{array}$ & 40 & Yes/No \\
\hline 13. & $\begin{array}{l}\text { Nowicki } \quad \& \\
\text { Strickland }\end{array}$ & 1973 & $\begin{array}{l}\text { CNSIE Children's Nowicki- } \\
\text { Strickland } \quad \text { Internal-External } \\
\text { Control Scale }\end{array}$ & 40 & Yes/No \\
\hline 14. & $\begin{array}{l}\text { Mischel, Zeiss \& } \\
\text { Zeiss }\end{array}$ & 1974 & $\begin{array}{l}\text { Stanford Preschool Internal- } \\
\text { External Scale }\end{array}$ & 14 & Forced-choice \\
\hline 15. & $\begin{array}{l}\text { Gruen, Korte \& } \\
\text { Baum }\end{array}$ & 1974 & $\begin{array}{l}\text { Group Measure of Locus of } \\
\text { Control }\end{array}$ & 38 pictures & Forced-choice \\
\hline 16. & Nowicki \& Duke & $1974 \mathrm{a}$ & $\begin{array}{l}\text { PPNSIE Pre-school and Primary } \\
\text { Nowicki-Strickland Internal- } \\
\text { External Control Scale }\end{array}$ & 26 & Yes/No \\
\hline 17. & Nowicki \& Duke & $1974 b$ & $\begin{array}{lcr}\text { ANSIE } & \text { Adult } & \text { Nowicki- } \\
\text { Strickland } & \text { Internal-External } \\
\text { Control Scale } & & \\
\end{array}$ & 40 & Yes/No \\
\hline 18. & $\begin{array}{l}\text { Duke, Shaheer \& } \\
\text { Nowicki }\end{array}$ & 1974 & $\begin{array}{l}\text { GNSIE Geriatric Nowicki- } \\
\text { Strickland } \\
\text { Internal-External Control Scale }\end{array}$ & 38 & Yes/No \\
\hline 19. & Louden & 1978 & $\begin{array}{l}\text { Locus of Control Scale for } \\
\text { Minority groups }\end{array}$ & 12 & Yes/No \\
\hline 20. & Duke \& Lewis & 1979 & $\begin{array}{lr}\text { BPPNSIE } & \text { Black Pre-school and } \\
\text { Primary } & \text { Nowicki-Strickland }\end{array}$ & 26 & Yes/No \\
\hline
\end{tabular}




\begin{tabular}{|c|c|c|c|c|c|}
\hline & & & Internal-External Scales & & \\
\hline 21. & $\begin{array}{ll}\text { Dahlquist } \quad \& \\
\text { Ottinger }\end{array}$ & 1983 & $\begin{array}{l}\text { Locus of Control Scale for } \\
\text { Children's Perception of Social } \\
\text { Interactions }\end{array}$ & 48 & Yes/No \\
\hline 22. & Connell & 1985 & $\begin{array}{l}\text { Multidimensional Measure of } \\
\text { Children's Perception of Control }\end{array}$ & 48 & $\begin{array}{l}\text { Four-point: } \\
\text { True/False }\end{array}$ \\
\hline 23. & Richaud de Minzi & 1991 & $\begin{array}{l}\text { A new multidimension children } \\
\text { Locus of Control Scale }\end{array}$ & $\begin{array}{l}45,32,16- \\
\text { item versions }\end{array}$ & Yes/No \\
\hline \multicolumn{6}{|c|}{ Parental Locus of Control } \\
\hline 24. & Campis et al. & 1986 & Parenting Locus of Control Scale & 48 & $\begin{array}{l}\text { Five-point } \\
\text { Agree-disagree }\end{array}$ \\
\hline 25. & $\begin{array}{l}\text { Tinsley } \\
\text { Holtgrave }\end{array}$ & 1989 & Parental Health Belief Scales & 20 & $\begin{array}{l}\text { Six-point Likert } \\
\text { scale }\end{array}$ \\
\hline 26. & Furnham & 1992 & Parental Locus of Control Scale & 60 & $\begin{array}{l}\text { Seven-point } \\
\text { Agree-disagree }\end{array}$ \\
\hline
\end{tabular}

\section{Work related Locus of Control}

\begin{tabular}{|c|c|c|c|c|c|}
\hline 27. & Jones \& Wuebker & 1985 & Safety Locus of Control Scale & 17 & $\begin{array}{l}\text { Six-point } \\
\text { Agree-disagree }\end{array}$ \\
\hline 28. & Furnham & 1986 & Economic Locus of Control & 40 & $\begin{array}{l}\text { Seven-point } \\
\text { Agree-disagree }\end{array}$ \\
\hline 29. & $\begin{array}{l}\text { Montag } \quad \& \\
\text { Comrey }\end{array}$ & 1987 & $\begin{array}{lll}\text { Driver Internality, } & \text { Driver } \\
\text { Externality } & \text { Scale }\end{array}$ & $\begin{array}{l}16(\mathrm{DI}) \\
14(\mathrm{DE})\end{array}$ & $\begin{array}{l}\text { Six-point } \\
\text { Agree-disagree }\end{array}$ \\
\hline 30. & Spector & 1988 & Work Locus of Control & 16 & $\begin{array}{l}\text { Six-point } \\
\text { Agree-disagree }\end{array}$ \\
\hline 31. & $\begin{array}{l}\text { Trice, Haire \& } \\
\text { Elliott }\end{array}$ & 1989 & Career Locus of Control & 18 & True/ False \\
\hline 32. & $\begin{array}{l}\text { Furnham, Sadka } \\
\text { \& Brewin }\end{array}$ & 1991 & $\begin{array}{l}\text { Occupational Attributional Style } \\
\text { Questionnaire }\end{array}$ & $\begin{array}{l}5 \text { positive \& } 5 \\
\text { negative } \\
\text { situations } \\
\text { rated }\end{array}$ & $\begin{array}{l}\text { Seven-point } \\
\text { scale }\end{array}$ \\
\hline \multicolumn{6}{|c|}{ Health Locus of Control } \\
\hline 33. & Duke \& Cohen & 1975 & Dental Health Locus of Control & 10 & Forced choice \\
\hline 34. & $\begin{array}{l}\text { Wallston, } \\
\text { Wallston, Kaplan } \\
\text { \& Maides }\end{array}$ & 1976 & Health Locus of Control Scale & 11 & $\begin{array}{ll}\text { Six- } & \text { point } \\
\text { Agree- } & \text { disagree }\end{array}$ \\
\hline 35. & $\begin{array}{l}\text { Wallston, } \\
\text { Wallston, \& De } \\
\text { Vellis }\end{array}$ & 1978 & $\begin{array}{l}\text { Multi-dimensional Health Locus } \\
\text { of Control }\end{array}$ & $3 * 12$ & $\begin{array}{l}\text { Six- } \quad \text { point } \\
\text { Agree-disagree }\end{array}$ \\
\hline 36. & Parcel \& Meyer & 1978 & $\begin{array}{l}\text { Children's Health Locus of } \\
\text { Control }\end{array}$ & 20 & Yes/No \\
\hline 37. & $\begin{array}{l}\text { Donovan \& } \\
\text { O'Leary }\end{array}$ & 1978 & $\begin{array}{l}\text { Drinking- related Locus of } \\
\text { Control Scale }\end{array}$ & 25 & $\begin{array}{l}\text { Forced-choice } \\
\text { pairing }\end{array}$ \\
\hline 38. & $\begin{array}{l}\text { Worrell \& } \quad \& \\
\text { Timility }\end{array}$ & 1981 & Alcoholic Responsibility Scale & 32 & Forced-choice \\
\hline 39. & Lau \& Ware & 1981 & $\begin{array}{l}\text { Health-Specific Locus of Control } \\
\text { Beliefs }\end{array}$ & 27 & $\begin{array}{l}\text { Seven-point } \\
\text { Agree -disagree }\end{array}$ \\
\hline 40. & Hill \& Bale & 1981 & $\begin{array}{l}\text { Mental Health Locus of Control } \\
\text { and Origin }\end{array}$ & $\begin{array}{l}\text { Control-28 } \\
\text { Origin-26 }\end{array}$ & $\begin{array}{l}\text { Seven-point } \\
\text { Relevant- } \\
\text { irrelevant } \\
\end{array}$ \\
\hline 41. & Wood \& Letak & 1982 & Mental Health Locus of Control & 6 & $\begin{array}{l}\text { Four-point } \\
\text { Important- } \\
\text { unimportant }\end{array}$ \\
\hline
\end{tabular}




\begin{tabular}{|c|c|c|c|c|c|}
\hline 42. & Saltzer & 1982 & Weight Locus of Control & 4 & $\begin{array}{l}\text { Six-point } \\
\text { Agree-disagree }\end{array}$ \\
\hline 43. & $\begin{array}{l}\text { Dowaliby, McKee } \\
\text { \& Maher }\end{array}$ & 1983 & $\begin{array}{l}\text { Locus of Control Inventory for } \\
\text { the Deaf }\end{array}$ & 23 & $\begin{array}{l}\text { Five-point } \\
\text { Agree-disagree }\end{array}$ \\
\hline 44. & $\begin{array}{l}\text { Bradley, Brewin, } \\
\text { Gamsu \& Moses }\end{array}$ & 1984 & $\begin{array}{l}\text { Perceived Control of Diabetes } \\
\text { Mellitus }\end{array}$ & $\begin{array}{l}6 \text { hypothetical } \\
\text { events: } 7 \\
\text { rating of each }\end{array}$ & $\begin{array}{l}\text { Seven-point } \\
\text { different for } \\
\text { each of the } \\
\text { seven ratings. }\end{array}$ \\
\hline 45. & Catania et al. & 1984 & Dyadic Sex Regulation Scale & 11 & $\begin{array}{l}\text { Seven-point } \\
\text { Agree-disagree }\end{array}$ \\
\hline 46. & $\begin{array}{l}\text { O’Connell \& } \quad \& \\
\text { Price }\end{array}$ & 1985 & Heart Disease Locus of Control & 20 & $\begin{array}{l}\text { Six-point } \\
\text { Agree-disagree }\end{array}$ \\
\hline 47. & Schroeder & 1985 & Labour in Childbirth & 20 & $\begin{array}{l}\text { Six-point } \\
\text { Agree-disagree }\end{array}$ \\
\hline 48. & Nicassio et al. & 1985 & Arthritis Helplessness Index & 15 & $\begin{array}{l}\text { Four-point } \\
\text { Agree-disagree }\end{array}$ \\
\hline 49. & De Vellis et al. & 1985 & Children's Recovery from Illness & 24 & $\begin{array}{l}\text { Six-point } \\
\text { Agree-disagree }\end{array}$ \\
\hline 50. & Labs \& Wurtale & 1986 & Fetal Health Locus of Control & 12 & $\begin{array}{l}\text { Six-point } \\
\text { Agree-disagree }\end{array}$ \\
\hline 51. & $\begin{array}{lr}\text { Ferraro, } & \text { Price, } \\
\text { Desmond } & \& \\
\text { Roberts } & \\
\end{array}$ & 1987 & Diabetes Locus of Control & 25 & $\begin{array}{l}\text { Six- } \quad \text { point } \\
\text { Agree-disagree }\end{array}$ \\
\hline 52. & Gamsu \& Bradley & 1987 & $\begin{array}{l}\text { Staff Perceived Control of } \\
\text { Diabetics }\end{array}$ & $\begin{array}{l}6 \text { hypothetical } \\
\text { events: } 7 \\
\text { rating of each }\end{array}$ & $\begin{array}{l}\text { Seven-point } \\
\text { different for } \\
\text { each of the } \\
\text { seven ratings. }\end{array}$ \\
\hline 53. & $\begin{array}{l}\text { Whitman, } \\
\text { Desmond } \\
\text { \& Price }\end{array}$ & 1987 & $\begin{array}{l}\text { Depression Locus of Control } \\
\text { Scale }\end{array}$ & 12 & $\begin{array}{l}\text { Six-point } \\
\text { Agree-disagree }\end{array}$ \\
\hline 54. & Stanton & 1987 & Hypertension Locus of Control & 4 & $\begin{array}{l}\text { Seven-point } \\
\text { Agree-disagree }\end{array}$ \\
\hline 55. & Pruyn et al. & 1988 & Cancer Locus of Control & 22 & $\begin{array}{l}\text { Six-point } \\
\text { Agree-disagree }\end{array}$ \\
\hline 56. & $\begin{array}{l}\text { Partridge } \quad \& \\
\text { Johnson }\end{array}$ & 1989 & $\begin{array}{l}\text { Control of Recovery from } \\
\text { Physical Disability }\end{array}$ & 9 & $\begin{array}{l}\text { Seven-point } \\
\text { Agree-disagree }\end{array}$ \\
\hline 57. & Stotland \& Zuroff & 1990 & Dieting Beliefs Scale & 16 & $\begin{array}{l}\text { Six-point } \\
\text { Agree-disagree }\end{array}$ \\
\hline 58. & Bradley et al. & 1990 & $\begin{array}{l}\text { Perceived Control of Tablet- } \\
\text { treated Diabetics }\end{array}$ & $\begin{array}{l}5 \text { hypothetical } \\
\text { events: } 7 \\
\text { rating of each }\end{array}$ & $\begin{array}{l}\text { Seven-point } \\
\text { different for } \\
\text { each of the } \\
\text { seven ratings. }\end{array}$ \\
\hline 59. & Watson et al. & 1990 & Cancer Locus of Control & 22 & $\begin{array}{l}\text { Six-point } \\
\text { Agree-disagree }\end{array}$ \\
\hline 60. & Skevington & 1990 & Belief in Pain Questionnaire & 15 & $\begin{array}{l}\text { Six-point } \\
\text { Agree-disagree }\end{array}$ \\
\hline 61. & $\begin{array}{l}\text { Martin, Holroyd } \\
\text { and Penzien }\end{array}$ & 1990 & $\begin{array}{l}\text { Headache-Specific Locus of } \\
\text { Control Scale }\end{array}$ & 33 & Likert type scale \\
\hline 62. & $\begin{array}{l}\text { Georgiou } \quad \& \\
\text { Bradley }\end{array}$ & 1992 & Smoking Specific Locus & 11 & $\begin{array}{l}\text { Six-point } \\
\text { Agree-disagree }\end{array}$ \\
\hline 63. & Holt & 2001 & $\begin{array}{l}\text { Spiritual Health Locus of Control } \\
\text { Scales }\end{array}$ & 14 & $\begin{array}{l}\text { Five-point } \\
\text { Likert scale }\end{array}$ \\
\hline
\end{tabular}




\begin{tabular}{|c|c|c|c|c|c|}
\hline 64. & Long & 2007 & $\begin{array}{l}\text { Oral Health Locus of Control } \\
\text { Scale }\end{array}$ & 68 & $\begin{array}{l}\text { Multiple choice } \\
\text { questions, } \\
\text { Yes/No } \\
\text { Likert type scale } \\
\text { ratings }\end{array}$ \\
\hline \multicolumn{6}{|c|}{ Misc. Locus of Control } \\
\hline 65. & Rose \& Medway & 1981 & Teacher Locus of Control Scale & 25 & Forced-choice \\
\hline 66. & Reid \& Ziegler & 1981 & Desired Control Scale & 22 & $\begin{array}{l}\text { Five-point } \\
\text { Desirable- } \\
\text { undesirable }\end{array}$ \\
\hline 67. & $\begin{array}{l}\text { Miller, Lefcourt } \\
\text { \& Ware }\end{array}$ & 1983 & Marital Locus of Control Scale & 44 & $\begin{array}{l}\text { Six-point } \\
\text { Agree-disagree }\end{array}$ \\
\hline 68. & Trice & 1985 & Academic Locus of Control & 28 & True/False \\
\hline 69. & $\begin{array}{l}\text { McCready \& } \\
\text { Long }\end{array}$ & 1985 & $\begin{array}{l}\text { Exercise Objectives Locus of } \\
\text { Control }\end{array}$ & 18 & $\begin{array}{l}\text { Five-point } \\
\text { agree-disagree }\end{array}$ \\
\hline 70. & Rounds \& Erdahl & 1988 & Nuclear Locus of Control Scale & 22 & $\begin{array}{l}\text { Six-point } \\
\text { Agree-disagree }\end{array}$ \\
\hline 71. & $\begin{array}{l}\text { Le Brasseur, } \\
\text { Blackford \& } \\
\text { Whissell }\end{array}$ & 1988 & Tenant Locus of Control & 26 & $\begin{array}{l}\text { Five-point } \\
\text { agree-disagree }\end{array}$ \\
\hline 72. & $\begin{array}{l}\text { Whitehead \& } \\
\text { Corbin }\end{array}$ & 1988 & Fitness Locus of Control & 18 & $\begin{array}{l}\text { Six-point agree- } \\
\text { disagree }\end{array}$ \\
\hline 73. & Pugh & 1992 & Prison Locus of Control Scale & 20 & $\begin{array}{l}\text { Ten-point } \\
\text { Agree-disagree }\end{array}$ \\
\hline 74. & Dag \& Haceteppe & 2002 & $\begin{array}{l}\text { Dag and Haceteppe Locus of } \\
\text { Control Scale }\end{array}$ & 47 & Likert type scale \\
\hline 75. & Ozkan \& Lajunen & 2005 & Traffic Locus of Control Scale & 17 & Agree-disagree \\
\hline
\end{tabular}

Source: Complied from the related reports

The list of locus of control scales still continues. The present study adapts Rotter's original LOC scale with few changes needed for the study and attempts to assess the locus of control of individual investors, so as to segment them into diverse clusters with different characteristics. The study also tries to analyse the impact of locus of control on the savings and investment behaviour of individual investors.

\section{Objectives of the study:}

The study has been pursued with the following objectives;

1. To assess the LOC of individual investors.

2. To segment and profile the individual investors on the basis of their LOC.

3. To examine the relationship between LOC and savings behaviour of individual investors.

4. To analyse the bond between LOC and investment behaviour of individual investors.

\section{Research methodology:}

The present study is based on primary data collected from the savers $(26.95 \%)$ and investors $(61.61 \%)$ of the working class residing in Ernakulam (NCAER, 2011, p.24). The population of study consists of the working class residing in Kerala. The district of Ernakulam was selected as it amounts for the highest workforce in Kerala, i.e,12,49,343 workers (Census 2011). As a result, the current study has a population size of $11,06,418[12,49,343 *(26.95 \%+61.61 \%)]$. Using Raosoft1991 sample size calculator a sample size of 97 has been arrived having a confidence level of $95 \%$. This has been rounded off to 100 for the ease of calculation.

Commercial banks are identified for the purpose of conducting the present study as each and every saver or investor will be having a bank account. The banks and respondents were selected using multistage judgemental sampling. Out of the 125 questionnaires distributed during the period, January $20^{\text {th }}$ to $30^{\text {th }}, 2020,100(80 \%)$ questionnaires were found completed and were used for data analysis.

The questionnaire for the study has four parts. Part A explores the demographic characteristics of the individual respondents using 9 questions. Part B consists of 4 questions relating to the savings behaviour of the individual. Part $\mathrm{C}$ portrays the investment behaviour of individuals and Part $\mathrm{D}$ measures the LOC of individuals. Rotter's LOC Scale was adapted for the purpose of measuring the LOC of respondents. The questionnaire's content validity was checked by a panel of experts, and the criteria validity and construct validity were tested. Survey instrument's reliability was tested using Cronbach Alpha. 
The Cronbach's alpha value is 0.806 , Cronbach's alpha value based on standardized items is 0.796 (Cronbach, 1951), Hotilins T Squared value is $129.759, \mathrm{~F}$ value is 5.588 and the significant value is 0.0000 . This means that the statements used in the questionnaire and the sample size are reliable and adequate at more than 99 percentage level of confidence.

The locus of control data showed a kurtosis of 0.096 and skewness of 0.042 , which are well within the normally accepted standards of \pm 1.96 (Cramer, 1998). The data collected was tested for its normality, by also applying the Shapiro-Wilk tests which showed a significance value of 0.075 , indicating that the data is normally distributed. The histogram and normal Q-Q plots also indicates that the data is normal.

Figure 1. Normality of the data

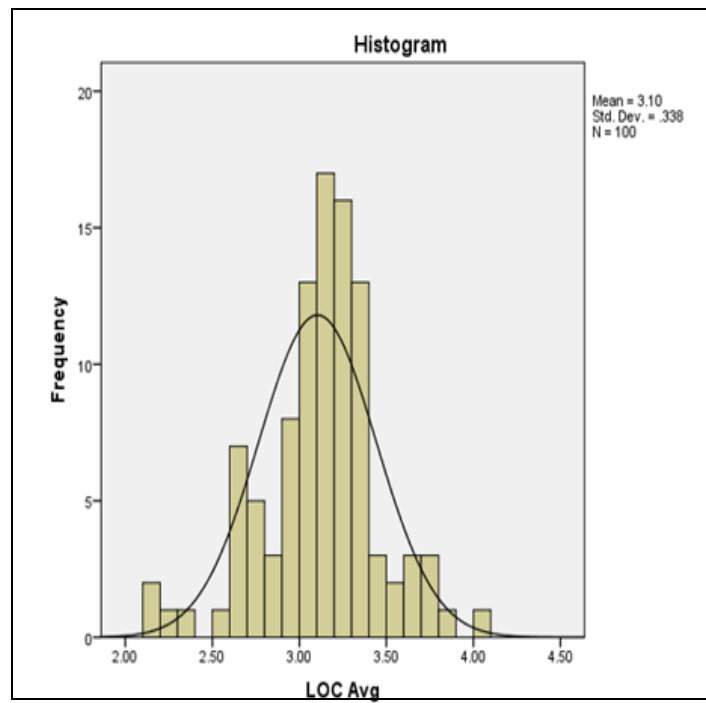

Source: Primary data

This study considers the areas of internal and external locus of control, savings and investment patterns, as components of individual investor behaviour. To assess the level of locus of control of each individual, 20 statements were provided -7 relating to external LOC and 13 statements relating to internal LOC. Respondents were asked to mark their opinions on a five-point Likert scale ranging from strongly agree (5) to strongly disagree (1). Then their opinions were averaged to determine their locus of control. Finally, respondents were divided into individuals having internal and external LOC based on their LOC scale value.

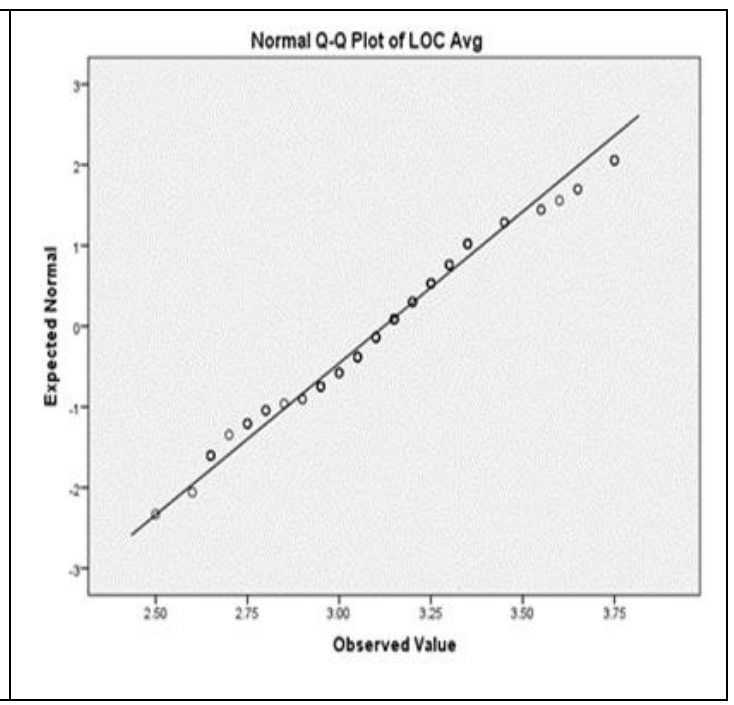

\section{Results \& discussions:}

\section{Demographic profile of Individual Investors}

Analysis of the demographic profile of the respondents revealed that $76 \%$ of the respondents were of the age group $19-40$ i.e., young adults while only $24 \%$ were in the age group of 41-60 i.e., adults. Out of the 100 respondents, 48 respondents were female and 52 respondents were male. Out of the respondents, $18 \%$ were under graduates, $45 \%$ were postgraduates and $37 \%$ had professional degrees. It was seen that $56 \%$ of the investors had low income i.e., below 300000/- and $44 \%$ of the investors belonged to the high-income bracket. Majority of the investors (57\%) were government employees. Other important demographic and socio-economic details are shown in Table 2.

Table 2. Demographic and socio-economic profile of individual investors.

\begin{tabular}{|c|c|c|c|c|c|}
\hline & & Frequency & & & Frequency \\
\hline \multirow[t]{2}{*}{ Age } & $\begin{array}{l}\text { Young } \\
\text { Adults (19 to } \\
40)\end{array}$ & 76 & \multirow[t]{2}{*}{$\begin{array}{l}\text { Monthly } \\
\text { income }\end{array}$} & Low $(<300000)$ & 56 \\
\hline & $\begin{array}{l}\text { Adults (41 to } \\
60 \text { ) }\end{array}$ & 24 & & High $(\geq 300000)$ & 44 \\
\hline \multirow[t]{2}{*}{ Gender } & Male & 52 & \multirow[t]{2}{*}{ Occupation } & Government & 57 \\
\hline & Female & 48 & & Private & 43 \\
\hline Residential & Urban & 78 & Qualification & Under graduate & 18 \\
\hline
\end{tabular}




\begin{tabular}{|c|c|c|c|c|c|}
\hline \multirow[t]{3}{*}{ location } & & & & & \\
\hline & \multirow{2}{*}{ Rural } & \multirow[t]{2}{*}{22} & & Post graduate & 45 \\
\hline & & & & $\begin{array}{l}\text { Professional } \\
\text { degree }\end{array}$ & 37 \\
\hline \multirow[t]{4}{*}{$\begin{array}{l}\text { Number of } \\
\text { dependents }\end{array}$} & $<1$ & 4 & \multirow[t]{4}{*}{$\begin{array}{l}\text { Primary bread } \\
\text { winner }\end{array}$} & Self & 46 \\
\hline & $1-3$ & 44 & & Spouse & 24 \\
\hline & $4-6$ & 52 & & Both & 9 \\
\hline & $>6$ & 0 & & Parents & 21 \\
\hline
\end{tabular}

Source: Primary data

\section{Internal Locus of Control}

The locus of control of individuals were assessed through the Rotter's LOC scale provided in part D of the questionnaire. It contained 20 statements- 13 statements relating to internal LOC and 7 relating to external LOC. The mean of the internal LOC statements is given in Table 3.

Table 3. Internal Locus of Control Statements

\begin{tabular}{|l|l|l|l|}
\hline $\begin{array}{l}\text { Sl. } \\
\text { No. }\end{array}$ & Statements & $\begin{array}{l}\text { Mean } \\
\text { Standard } \\
\text { deviation }\end{array}$ \\
\hline 1. & People's misfortunes result from the mistakes they make. & 3.07 & 1.06 \\
\hline 2. & In the long run people get the respect they deserve in this world. & 3.15 & 1.11 \\
\hline 3. & It's one's experiences in life which determine what they are in life. & 3.51 & 1.02 \\
\hline 4. & I have often found out what is going to happen will happen. & 3.02 & .87 \\
\hline 5. & $\begin{array}{l}\text { Trusting fate has never turned out as well for me as making a decision to take a } \\
\text { definite course of action. }\end{array}$ & 2.93 & .81 \\
\hline 6. & Becoming a success is a matter of hard work; luck has little or nothing to do with it. & 2.98 & 1.18 \\
\hline 7. & Getting a good job depends mainly on being in the right place at the right time. & 3.36 & 1.07 \\
\hline 8. & When I make plans, I am almost certain that I can make them work. & 3.30 & 1.05 \\
\hline 9. & $\begin{array}{l}\text { It is impossible for me to believe that chance or luck plays an important role in my } \\
\text { life. }\end{array}$ & 2.85 & .85 \\
\hline 10. & Usually, when I plan to do something, I can carry it out. & 3.33 & .91 \\
\hline 11. & In general, I think about a decision before taking action. & 3.35 & .98 \\
\hline 12. & $\begin{array}{l}\text { It is better to save up for something and buy it only when you have the money to } \\
\text { pay. }\end{array}$ & 3.00 & 1.22 \\
\hline 13. & Being in debt shows that you cannot manage yours finances properly. & 2.71 & 1.20 \\
\hline
\end{tabular}

\section{Source: Primary data}

The mean value of the internal LOC ranges between 5 and 1 . Since most of the mean values as shown in table 3 is more than 3 and only four values are below it, but not so low, it can be inferred that the individual investors in Kerala have more internal locus of control. They believe in their own judgement and rely on hard work rather than luck and faith. It can be seen that the impact of locus of control on debt management is only moderate $($ mean $=2.71)$.

Table 4. Internal Locus of Control of Individual Investors.

\begin{tabular}{|l|l|}
\hline Internal LOC & Percentage \\
\hline Low & 2 \\
\hline Medium & 95 \\
\hline High & 3 \\
\hline Total & 100 \\
\hline
\end{tabular}

Source: Primary data

Table 4 . depicts that majority $(95 \%+3 \%)$ of the individual investors have medium or high level of internal locus of control i.e., they believe in their own capabilities rather than the external environment. These investors portray the quality of self- efficacy in their behaviour, as a result they are highly self- motivated to achieve their goals. Only $2 \%$ the of investors have low internal LOC, and hence they need to be externally motivated to achieve the desired results. However, it cannot be ignored, that the extent to which an investor can be motivated externally is limited.

\section{External Locus of Control}

The seven statements relating to external locus of control revealed a mean value as shown in the table 5 . 
Table 5. External Locus of Control Statements

\begin{tabular}{|l|l|l|l|}
\hline $\begin{array}{l}\text { Sl. } \\
\text { No. }\end{array}$ & Statements & $\begin{array}{l}\text { Mean } \\
\text { deviation }\end{array}$ \\
\hline 1. & Many of the unhappy things in people's life are partly due to bad luck. & 3.46 & .83 \\
\hline 2. & $\begin{array}{l}\text { To improve standard of living unfortunately, an individual's worth passes unrecognized no } \\
\text { matter how hard he tries. }\end{array}$ & 3.31 & .93 \\
\hline 3. & Heredity plays a major role in determining one's personality. & 2.88 & 1.04 \\
\hline 4. & $\begin{array}{l}\text { It is not always wise to plan too far ahead because many things turn out to be a matter of good } \\
\text { or bad fortune anyhow. }\end{array}$ & 2.87 & 1.10 \\
\hline 5. & Many times, I feel that I have little influence over the things that happen to me. & 2.96 & .93 \\
\hline 6. & The best laid plans often go astray. & 3.18 & .88 \\
\hline 7. & Being in debt shows that you cannot manage your finances properly. & 3.22 & 1.15 \\
\hline
\end{tabular}

\section{Source: Primary data}

Among the 7 statements relating to external locus of control have a mean value below 3 and the rest of the statements do not have very high values, which indicates that the individual investors, do not have much reliance on their faith and luck. They mainly focus on their hard work to achieve their goals and objectives. Mean value up to 2 is categorized as low, values between 2 and 4 as medium and above 4 as high.

Table 6. External Locus of Control of Individual Investors

\begin{tabular}{|l|l|}
\hline External LOC & Percentage \\
\hline Low & 9 \\
\hline Medium & 87 \\
\hline High & 4 \\
\hline Total & 100 \\
\hline
\end{tabular}

Source: Primary data

As shown in table 6., majority (87\%) of the individuals believe in external forces, but at the same time they value their own individual opinions. Only $4 \%$ strongly believe that the external environment has an influence on their life events and $9 \%$ have considerably low external locus of control, which means that they are highly internally motivated. This leads to the conclusion that, external LOC has less influence on an individual investor.

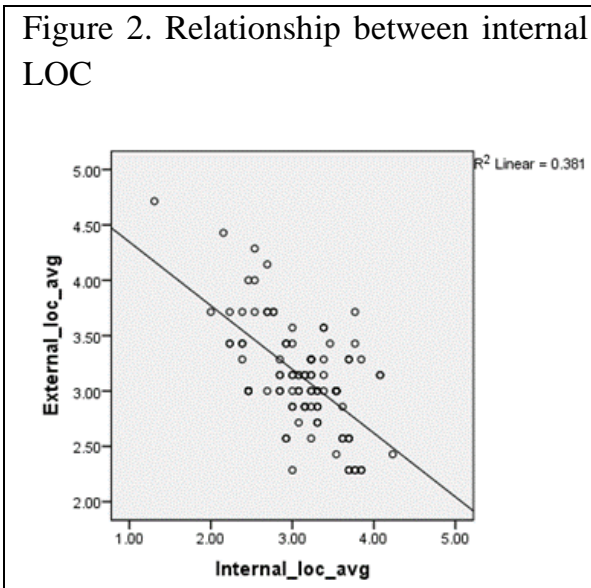

Source: Primary data

\section{Relationship between Internal and External LOC}

In order to determine whether the internal and external locus of control, exhibited significant correlation, Pearson's correlation coefficient was used. On analysis it was seen that the correlation between internal and external locus of control was significant at 0.01 level of significance and generated a correlation coefficient -0.617 . This indicates that the internal and external LOC are not independent of each other, both these traits are present in an individual investor but at varying levels. Figure 2. Depicts the relationship between the internal and external locus of control with a linear trend line.

\section{Investor Segmentation}

Investor segmentation is the rule of the day. It refers to the process of classifying individual investors into different subgroups based on their personality traits. Several studies have been conducted in this field of research by categorizing investors into various subgroups based on their; level of knowledge, allocation strategies and personality (Bailard et al. 1986; Harrison, 1994; Gunnarsson and Wahlund, 1997; Waneryd, 2001; Wood and Zaichkowsky, 2004; Pompian, 2012 ). The present study tries to segment investors based on their locus of control. As we have already noted investors have varying levels of internal and external locus of control. Keeping this in view, segmentation is made with the help of cluster analysis. Cluster analysis classifies individuals or objects, on the basis of their character. The clusters so formed will exhibit high internal (within- cluster) homogeneity and high external(between-cluster) heterogeneity (Hair et al. 1998). In order to determine the number of clusters to be formed, a hierarchical cluster analysis was done in the initial stage. After applying hierarchical cluster analysis, it was found that the investors can be classified into 3 clusters. 


\begin{tabular}{|l|l|l|l|}
\hline \multicolumn{4}{|l|}{ Table 7. Individual Investor Segmentation } \\
\begin{tabular}{|l|l|l|l|}
\hline & $\begin{array}{l}\text { Cluster 1 } \\
\text { (Internals) }\end{array}$ & $\begin{array}{l}\text { Cluster 2 } \\
\text { (Externals) }\end{array}$ & $\begin{array}{l}\text { Cluster 3 } \\
\text { (Moderates) }\end{array}$ \\
\hline $\begin{array}{l}\text { External } \\
\text { LOC }\end{array}$ & 2.78 & 3.80 & 3.10 \\
\hline $\begin{array}{l}\text { Internal } \\
\text { LOC }\end{array}$ & 3.63 & 2.39 & 3.05 \\
\hline $\begin{array}{l}\text { Number } \\
\text { of } \\
\text { individual } \\
\text { investors }\end{array}$ & 34 & 19 & 47 \\
\hline
\end{tabular}
\end{tabular}

Source: Primary data
Figure 3. Investor Clusters

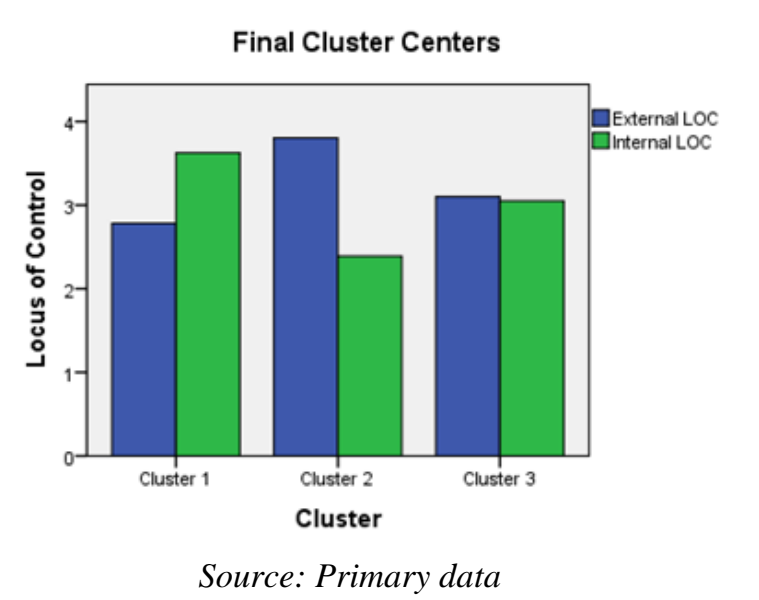

study, $47 \%$ of the individuals are moderates i.e., they have both the qualities of internals and externals.

\section{Validation of Segmentation}

Discriminant analysis is used in the following section to profile and validate the cluster solutions formed on the basis of locus of control. Under discriminant analysis, when there are three clusters, two discriminant functions are formed. In this case the first function relates to external LOC and second function relate to internal LOC. The figure 4. Clearly indicates that the classification based on LOC is suitable and distinct cluster have been formed. 


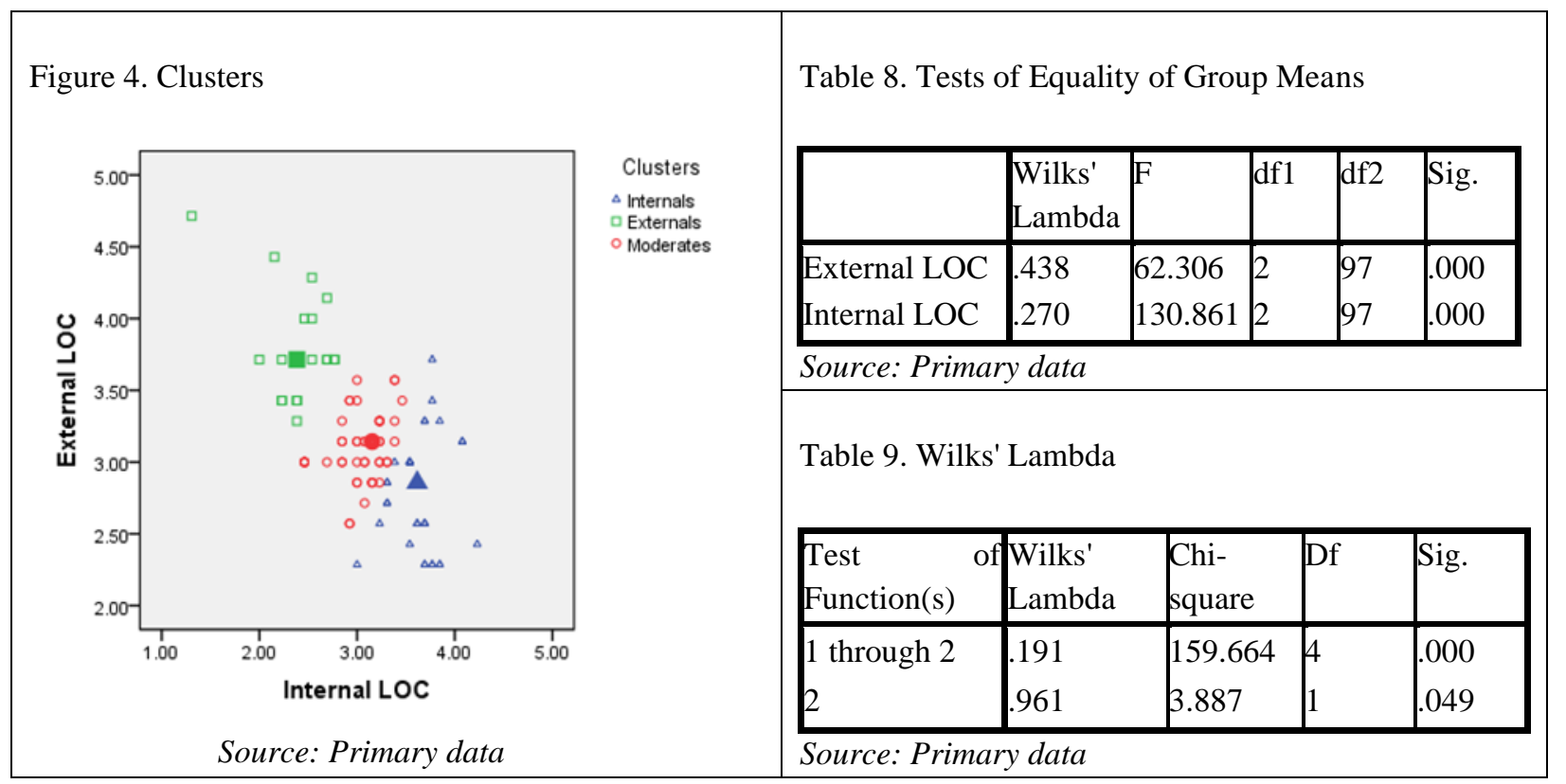

The test of equality of group means also revealed significance, which indicates that there is significant differences in the clusters formed. The group correlations were 0.022 and the Box's M test (sig. $=0.003$ ) also states that there is multivariate normality in the clusters formed or their covariances are significantly different. All this indicate that the profiling done on the bases of locus of control is correct. Wilk's Lambda showed significance for the test of function 1 through 2, which indicates that the discriminant function formed has good prediction capabilities.

The classification results are as shown in table 10. It indicates that $96 \%$ of the classification is correct.

Table 10. Classification Results of Discriminant analysis

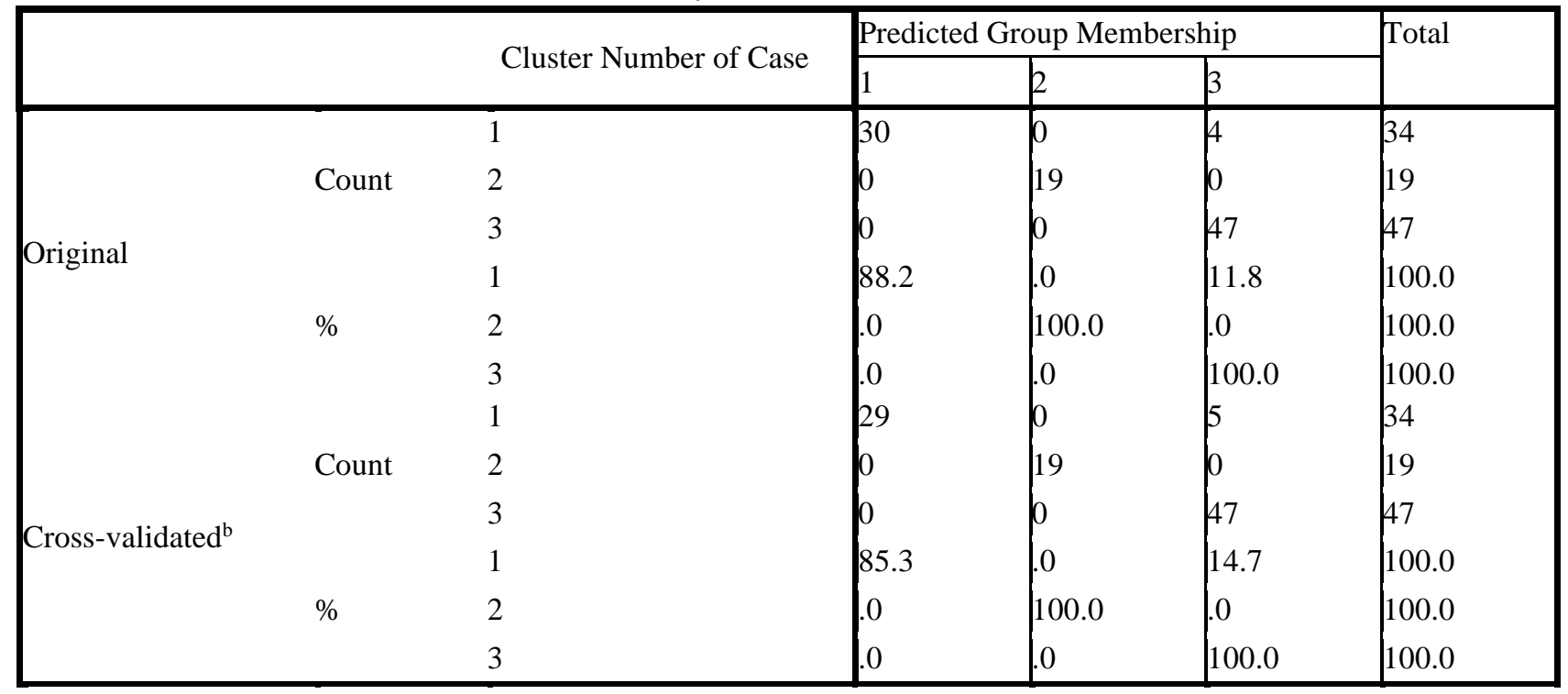

a. $96.0 \%$ of original grouped cases correctly classified.

b. Cross validation is done only for those cases in the analysis. In cross validation, each case is classified by the functions derived from all cases other than that case.

c. $95.0 \%$ of cross-validated grouped cases correctly classified.

\section{Source: Primary data}

\section{Savings Behaviour of Individuals}

Individuals save for a monetary buffer, for their children, their retirement, for particular transactions, or for "rainy days." In order to abstain from immediate spending and to save money for "later," future time preference and self-control are required. Saving was seen as morally good for average individuals in the Middle Ages, and spending was seen as morally bad (Van Raaij, 2016). Individual portray different savings behaviour like some may save a part of their monthly income regularly or some may save only when they have surplus money with them, all these depend on their inner cognitions. Table 10. Portrays the savings behaviour of individual investors.

Table 11. Savings Behaviour 


\begin{tabular}{|l|l|}
\hline Savings Behaviour & Percentage \\
\hline $\begin{array}{l}\text { Save regularly, keep aside a } \\
\text { part of the monthly income. }\end{array}$ & 63 \\
\hline $\begin{array}{l}\text { Spend regularly the self - } \\
\text { earned income and save others } \\
\text { income. }\end{array}$ & 16 \\
\hline $\begin{array}{l}\text { Spend income of others and } \\
\text { save self-earned income. }\end{array}$ & 21 \\
\hline
\end{tabular}

Source: Primary data
The above table shows that majority of the individuals $(63 \%)$ save their income regularly i.e., they keep aside a part of their monthly income for future needs and contingencies, whereas $21 \%$ of individuals spend the income of others and save their own income i.e., they have a habit of spending along with saving. At last, $16 \%$ of individuals spend their self-earned income and save the income of others in their family. This portrays the picture that, most of the individuals have an inherent savings behaviour in them. In order to analyse the impact of LOC on the savings behaviour of individuals, discriminant analysis was used.
Table 12. Structure Matrix

\begin{tabular}{|l|l|l|}
\hline \multirow{2}{*}{} & \multicolumn{2}{|l|}{ Function } \\
\cline { 2 - 3 } & $\mathbf{1}$ & $\mathbf{2}$ \\
\hline $\begin{array}{l}\text { External } \\
\text { LOC }\end{array}$ & .938 & -.347 \\
\hline $\begin{array}{l}\text { Internal } \\
\text { LOC }\end{array}$ & -.307 & .952 \\
\hline
\end{tabular}

Source: Primary data
Table 13. Attributes of Discriminant analysis

\begin{tabular}{|l|l|l|l|l|l|l|}
\hline $\begin{array}{l}\text { Test of } \\
\text { function(s) }\end{array}$ & $\begin{array}{l}\text { Wilk's } \\
\text { Lambda }\end{array}$ & $\begin{array}{l}\text { Eigen } \\
\text { Value }\end{array}$ & $\begin{array}{l}\text { Chi- } \\
\text { square }\end{array}$ & df & $\begin{array}{l}\text { Canonical } \\
\text { Correlation }\end{array}$ & Sig. \\
\hline $\mathbf{1}$ through & .866 & .143 & 13.882 & 4 & .354 & .008 \\
$\mathbf{2}$ & & & & & & \\
\hline $\mathbf{2}$ & .990 & .010 & .976 & 1 & .100 & .323 \\
\hline
\end{tabular}

Source: Primary data
Table.12 indicates the structure matrix of the canonical discriminant function. The matrix indicates that two discriminant functions can be formed viz.

$\mathrm{Z} 1=0.938 *$ External LOC and

\section{$\mathrm{Z} 2=0.952 *$ Internal LOC}

Even though two separate discriminant functions can be drawn, only function 1 appropriately distinguishes between the various savings behaviours. The Eigen value (0.143) is high and Wilk's Lambda (0.866) is comparatively low for function 1 as compared to function 2. Moreover, there is a high Chisquare value (13.882) and canonical correlation (0.354) for function 1. As a result, function 1 has a better model fit of predictability and is statistically significant. This indicates that the external LOC of individuals have a greater influence on their savings behaviour compared to internal LOC. Chi-square analysis is used to study the relationship between savings behaviour and external LOC. The chi-square value (42.469) indicates that there is significant relationship between savings behaviour and external LOC traits of individuals.

\section{Investment Behaviour of Individuals}

Investment behaviour is dependent on the uncertainty about the future and is therefore risky. In investment markets, news and rumours and the pace and availability of information play an important role. The main principles and interpretations of investment behaviour are risk inclination, risk preference, and attitude (Van Raaij, 2016). Biases and heuristics are employed by investors in their decisions to either invest or not, and how much to invest. Another consideration is herding: people prefer to mimic and obey other investors, possibly because of a lack of appropriate and reliable data and a lack of courage to behave in a different way. In the present study, five facets of individual investment behaviour are studied, namely; purpose of investment, investment avenues preferred, period of investment, sources of investment information, factors influencing investment decisions and its relationship with locus of control.

Firstly, the homogeneity of variances is tested using Levene statistic. Levene statistic is used to test the null hypothesis that the variances of the groups are the same. This is the basic assumption for applying ANOVA, if this is violated then we have to take steps to rectify it or use Welch's F, or BrownForsythe F tests, to compare the differences in means. In the current study, if Levene's test is not significant (i.e., the value of Sig. is more than .05) then we can proceed with ANOVA, otherwise we use Welch's F, or Brown-Forsythe F tests for comparing the means between the groups.

Table 14. Test of homogeneity of variances

\begin{tabular}{|l|l|l|l|l|}
\hline & $\begin{array}{l}\text { Levene } \\
\text { Statistic }\end{array}$ & df1 & df2 & Sig. \\
\hline Purpose of investment & 2.189 & 2 & 97 & .118 \\
\hline To meet old age need & 2.565 & 2 & 97 & .082 \\
\hline $\begin{array}{l}\text { To meet unforeseen } \\
\text { contingencies }\end{array}$ & 1.453 & 2 & 97 & .239 \\
\hline To enlarge income & 1.161 & 2 & 97 & .318 \\
\hline $\begin{array}{l}\text { To improve Standard of } \\
\text { Living }\end{array}$ & .987 & 2 & 97 & .376 \\
\hline To maximize revenue & .244 & 2 & 97 & .784 \\
\hline $\begin{array}{l}\text { To save for next } \\
\text { generation }\end{array}$ & 2.859 & 2 & 97 & .062 \\
\hline To become spend thrift & 2.189 & 2 & 97 & .118 \\
\hline Investment avenues & & & & \\
\hline Post office & .072 & 2 & 97 & .931 \\
\hline
\end{tabular}




\begin{tabular}{|l|l|l|l|l|}
\hline Fixed deposit & 5.879 & 2 & 97 & .004 \\
\hline Mutual Funds & .160 & 2 & 97 & .852 \\
\hline Insurance & 8.124 & 2 & 97 & .001 \\
\hline NBFC & 45.870 & 2 & 97 & .000 \\
\hline Jewellery & .322 & 2 & 97 & .726 \\
\hline Real estate & .072 & 2 & 97 & .931 \\
\hline Shares & .824 & 2 & 97 & .442 \\
\hline Period of investment & 1.968 & 2 & 97 & .145 \\
\hline Source of investment & & & & \\
\hline Electronic Media & .740 & 2 & 97 & .480 \\
\hline Print Media Family & 2.203 & 2 & 97 & .116 \\
\hline $\begin{array}{l}\text { Relatives, } \\
\text { Members }\end{array}$ & 1.621 & 2 & 97 & .203 \\
\hline Friends, Co- Workers & 1.231 & 2 & 97 & .296 \\
\hline $\begin{array}{l}\text { Expert Opinion } \\
\text { Consultants }\end{array}$ & .940 & 2 & 97 & .394 \\
\hline $\begin{array}{l}\text { Financial Professionals, } \\
\text { Brokers }\end{array}$ & 1.301 & 2 & 97 & .277 \\
\hline $\begin{array}{l}\text { Factors influencing } \\
\text { investment decision }\end{array}$ & & & & \\
\hline Factor - Less Risk & 7.310 & 2 & 97 & .001 \\
\hline $\begin{array}{l}\text { Factor -High Capital } \\
\text { Appreciation }\end{array}$ & 1.599 & 2 & 97 & .207 \\
\hline Factor - Regular Return & 1.059 & 2 & 97 & .351 \\
\hline Factor - Convenience & 1.965 & 2 & 97 & .146 \\
\hline $\begin{array}{l}\text { Factor -Terms of } \\
\text { Investment }\end{array}$ & 1.224 & 2 & 97 & .298 \\
\hline Factor -Liquidity & .248 & 2 & 97 & .781 \\
\hline
\end{tabular}

Source: Primary data

From table 14. it is evident that there is homogeneity of variances among the various groups, except, the investment avenues - Fixed deposits, Insurance, NBFC and factors influencing investment decision- Less risk. So only for these 4 variables, the present study uses Welch's F, or BrownForsythe $\mathrm{F}$ tests and for the remaining variables we use ANOVA, to compare the differences in mean.

Table 15. indicates the variance in means in the various variables used to study the impact of LOC on investment behaviour.

Table 15. ANOVA

\begin{tabular}{|l|l|l|}
\hline & F & Sig. \\
\hline Purpose of investment & & \\
\hline To meet old age need & .503 & .607 \\
\hline $\begin{array}{l}\text { To meet unforeseen } \\
\text { contingencies }\end{array}$ & .422 & .657 \\
\hline To enlarge income & 1.757 & .178 \\
\hline $\begin{array}{l}\text { To improve Standard of } \\
\text { Living }\end{array}$ & 1.424 & .246 \\
\hline To maximize revenue & 1.870 & .160 \\
\hline $\begin{array}{l}\text { To save for next } \\
\text { generation }\end{array}$ & 3.635 & .030 \\
\hline To become spend thrift & 1.777 & .175 \\
\hline Investment avenues & .203 & .816 \\
\hline Post office & .173 & .841 \\
\hline Mutual Funds & .099 & .906 \\
\hline Jewellery & .203 & .816 \\
\hline Real estate & \\
\hline
\end{tabular}

\begin{tabular}{|l|l|l|}
\hline Shares & .208 & .813 \\
\hline Period of investment & .264 & .769 \\
\hline Source of investment & & \\
\hline Electronic Media & .542 & .584 \\
\hline Print Media Family & .433 & .650 \\
\hline $\begin{array}{l}\text { Relatives, } \\
\text { Members }\end{array}$ & 9.082 & .000 \\
\hline Friends, Co- Workers & .777 & .463 \\
\hline $\begin{array}{l}\text { Expert Opinion } \\
\text { Consultants }\end{array}$ & 4.512 & .013 \\
\hline $\begin{array}{l}\text { Financial Professionals, } \\
\text { Brokers influencing }\end{array}$ & 3.560 & .032 \\
\hline $\begin{array}{l}\text { Factors Capital } \\
\text { investment decision }\end{array}$ & 2.133 & .124 \\
\hline $\begin{array}{l}\text { High } \\
\text { Appreciation }\end{array}$ & .095 & .909 \\
\hline Regular Return & .995 & .373 \\
\hline Convenience & .146 & .864 \\
\hline Terms of Investment & .624 & .538 \\
\hline Liquidity & \\
\hline Primary data & \\
\hline \multicolumn{1}{|c|}{. } & \\
\hline
\end{tabular}

Source: Primary data

It can be inferred from the above table that, the 3 clusters formed on the basis of their locus of control do not show much variation in their purpose of investment, except for saving money for the next generation $(\mathrm{F}$ value $=3.635$, $\mathrm{p}$ value $=0.03)$. In the case of investment avenues and the period of investment also the clusters do not show variations i.e., these 3 clusters are indifferent to the investment avenues and period of investment as their $\mathrm{p}$ values are all above 0.05. Regarding, the sources of investment information, the clusters show significant difference regarding information procured from relatives, family members, expert opinions, consultants, financial professionals and brokers ( $p$ value $=0.05)$. The clusters are indifferent towards information gathered from electronic, print media, friends and co-workers. All the 3 clusters give equal importance for the various factors influencing investment decisions ( $p$ value $>0.05$ ).

Table 16. Robust tests of equality of means.

\begin{tabular}{|l|l|l|l|l|l|}
\hline \multicolumn{7}{|l|}{} & Statistic & df1 & df2 & Sig. \\
\hline Investment avenue \\
\hline \multirow{2}{*}{$\begin{array}{l}\text { Fixed } \\
\text { deposits }\end{array}$} & Welch & 1.538 & 2 & 50.469 & .225 \\
\cline { 2 - 6 } & $\begin{array}{l}\text { Brown- } \\
\text { Forsythe }\end{array}$ & 1.643 & 2 & 81.052 & .200 \\
\hline Insurance & Welch & 4.155 & 2 & 45.206 & .022 \\
\cline { 2 - 6 } & $\begin{array}{l}\text { Brown- } \\
\text { Forsythe }\end{array}$ & 3.953 & 2 & 64.518 & .024 \\
\hline Factors influencing investment decision & & \\
\hline \multirow{2}{*}{ Less risk } & Welch & .366 & 2 & 41.687 & .696 \\
\cline { 2 - 6 } & $\begin{array}{l}\text { Brown- } \\
\text { Forsythe }\end{array}$ & .326 & 2 & 55.524 & .723 \\
\hline
\end{tabular}

Source: Primary data 
The robust tests of equality of means have been done for the above variables, as there was no homogeneity of variances found for these variables and hence ANOVA cannot be applied for such variables. Hence in this section the present study has used the robust tests of equality of means namely, Welch and Brown-Forsythe for comparing the means of the different clusters. The above table shows that only the investment avenue- insurance showed significant difference among the clusters i.e., the clusters showed difference in the investment pattern in insurance sector.

\section{Research implications:}

Locus of control is a very important psychological construct which has been researched over the centuries in various fields and dimensions. The researches done in this field are so vast and diversified that, it shows the relevance of the study. The present study helps us in analysing the locus of control of individuals and its impact on the savings and investment behaviour of individual investors in Kerala. Kerala is a state which is in the forefront in many respects compared to the other states in the country, so it is highly important that it is financially sound and financial soundness comes from a sound and clear mind which is not influenced by external factors. LOC measures this dependency or independency of the mind on the external factors. Thus, this highlights the relevance of the present study.

\section{Conclusion:}

Locus of control portrays the inner attitude of an individual. The data collected for the study revealed that most of the individuals in Kerala had more internal LOC compared to external LOC, i.e., they believed in themselves and their hard work rather than on fate, luck and other external factors. It was also seen that there existed a high correlation between internal and external LOC i.e., they do not exist independently, instead the study revealed that a person has both internal and external LOC at varying levels, under different situations. The study used LOC construct to segment individuals into 3 clusters; namely internals, externals and moderates. It was seen that most of the individuals in Kerala were moderates i.e., they exhibited both the qualities of internals and externals. Their traits varied according to different situations. The clusters so formed were tested for their suitability and validity using discriminant analysis and the classification was found to be correct and apt. Thus, in Kerala there is a mixture of LOC clusters, but mostly they are moderates who try to suffice situations rather than taking extreme decisions. The study also revealed that majority of the individuals in Kerala are savers (63\%) and external locus of control has an influence on the savings \& investment behaviour of individuals.

\section{Limitations of the study and scope for future research:}

As the study was conducted in selected districts of Kerala, the generalization of the study has its limitations. The results may vary if it is done in some other districts or states of India. Locus of control is a psychological phenomenon hence; it is subject to variations based on situations and difficult to measure accurately.

This study covers only some demographic and socio-economic factors, studies can be conducted for exploring more such factors: psychological factors or situational factors. Studies can also be conducted to explore the influence of locus of control on the risk tolerance of individuals

\section{References}

[1] Almlund, M., Duckworth, A. L., Heckman, J., \& Kautz, T. (2011). Personality psychology and economics. In Handbook of the Economics of Education (Vol. 4, pp. 1-181). Elsevier.

[2] Bailard, T.E., Biehl, D.L. and Kaiser, R.W. (1986). Personal Money Management, 5th ed., Science Research Associates, Chicago, IL

[3] Baker, H. K., \& Ricciardi, V. (2014). Investor behavior: The psychology of financial planning and investing. John Wiley \& Sons.

[4] Bandura, A. (1989). Regulation of cognitive processes through perceived self-efficacy. Developmental psychology, 25(5), 729.

[5] Battle, E. \& Rotter, J. (1963). Children's feelings of personal control as related to social class and ethnic group. Journal of Personality, 31, 402-490.

[6] Bialer, J. (1961). Conceptualization of success and failure in mentally retarded children. Journal of Personality, 29, 303-320.

[7] Bradley, C., Brewin, C. R., Gamsu, D. \& Moses, J. (1984). Development of scales to measure perceived control of diabetes mellitus and diabetes related health beliefs. Diabetic Medicine, 1, 213-21 8.

[8] Bradley, C., Lewis, K., Jennings, A. \& Ward, S. (1990). Scales to measure perceived control developed specifically for people with tablet-treated diabetes. Diabetic Medicine, 7, 685-694.

[9] Buddelmeyer, H., \& Powdthavee, N. (2016). Can having internal locus of control insure against negative shocks? Psychological evidence from panel data. Journal of economic behavior \& organization, 122, 88-109.

[10] Campis, L., Lyman, R. \& Prentice-Dunn, S. (1986). The parental locus of control scale: Development and validation. Journal of Clinical Child Psychology, 15, 260-267.

[11] Catania, J., McDermott, L. \& Wood, J. (1984). Assessment of locus of control: Situational 
specificity in the sexual context. Journal of Sex Research, 20, 310-324.

[12] Census of India Website : Office of the Registrar General \& Census Commissioner, India. (2021). Retrieved 20 February 2021, from http://censusindia.gov.in/

[13] Christelis, D., Jappelli, T., \& Padula, M. (2010). Cognitive abilities and portfolio choice. European Economic Review, 54(1), 18-38.

[14] Cobb-Clark, D. A. (2015). Locus of control and the labor market. IZA Journal of Labor Economics, 4(1), 1-19.

[15] Cobb-Clark, D. A., \& Schurer, S. (2013). Two economists' musings on the stability of locus of control. The Economic Journal, 123(570), F358F400.

[16] Cobb-Clark, D. A., \& Tan, M. (2011). Noncognitive skills, occupational attainment, and relative wages. Labour Economics, 18(1), 1-13.

[17] Cobb-Clark, D. A., Kassenboehmer, S. C., \& Schurer, S. (2014). Healthy habits: The connection between diet, exercise, and locus of control. Journal of Economic Behavior \& Organization, 98, 1-28.

[18] Cobb-Clark, D. A., Kassenboehmer, S. C., \& Sinning, M. G. (2016). Locus of control and savings. Journal of Banking \& Finance, 73, 113130.

[19] Connell, J. (1985). A new multidimensional measure of children's perceptions of control. Child Development, 56, 1018-1041.

[20] Cramer, D. (1998). Fundamental statistics for social research: step-by-step calculations and computer techniques using SPSS for Windows. Psychology Press.

[21] Crandall, V., Katkovsky, W. \& Crandall, V. (1965). Children's belief in their own control of reinforcement in intellectually-academic achievement situations. Child Development, 36, 91109.

[22] Cronbach, L. J. (1951). Coefficient alpha and the internal structure of tests. psychometrika, 16(3), 297-334.

[23] Dag, I. \& Haceteppe, A. (2002). Locus of Control Scale: Scale development, reliability, and validity. Turk Psikoloji Dergisi, 17, 77-92.

[24] Dahlquist, L. \& Ottinger, D. (1983). Locus of control and peer states: A scale for children's perceptions of social interactions. Journal of Personality Assessment, 47, 278-287.

[25] De Vellis, R., De Vellis, B., Revicki, D., Luria, S., Runyan, D. \& Briston, M. (1985). Development and validation of the child improvement locus of control
(CILC) scale. Journal of Social and Clinical Psychology, 39, 307-324.

[26] Dohmen, T., Falk, A., Huffman, D., \& Sunde, U. (2010). Are risk aversion and impatience related to cognitive ability?. American Economic Review, 100(3), 1238-60.

[27] Donovan, D. \& O'Leary, M. (1978). The drinkingrelated locus of control scale: Reliability, factor structure and validity. Journal of Studies on Alcohol, 39, 759-784.

[28] Dowaliby, F., McKee, B. \& Maher, H. (1983). A locus of control inventory for postsecondary hearing-impaired students. American Annals of the Deaf, 128, 884-889.

[29] Duke, M. \& Cohen, B. (1975). Locus of control as an indicator of patient co-operation. Journal of the American College of Dentists, 42, 174-178.

[30] Duke, M. \& Lewis, G. (1979). The measurement of locus of control in black preschool and primary school children. Journal of Personality Assessment, 43, 479-480.

[31] Duke, M., Shaheer, J. \& Nowicki, S. (1974). The determinants of locus of control in a geriatric population and subsequent test of the social learning model for interpersonal distance. Journal of Psychology, 86, 277-285.

[32] Duttweiler, P. (1984). The Internal Control Index: A newly developed measure of locus of control. Educational and Psychological Measurement, 44, 209-221.

[33] Ferraro, L., Price, J., Desmond, S. \& Roberts, S. (1987). Development of a diabetes locus of control scale. Psychological Reports, 61, 763-770.

[34] Furnham, A. (1986). Economic locus of control. Human relations, 39, 29-43.

[35] Furnham, A. (1992). A parental locus of control scale. Individual Differences Research, 8(3), 151163.

[36] Furnham, A., \& Steele, H. (1993). Measuring locus of control: A critique of general, children's, health-and work-related locus of control questionnaires. British journal of psychology, 84(4), 443-479.

[37] Furnham, A., Sadka, V. \& Brewin, C. (1991). The development of an occupational attributional style questionnaire. Journal of Organisational Behaviour, 13, 27-39.

[38] Gamsu, D. \& Bradley, C. (1987). Clinical staffs attributions about diabetes: Scale-development and staff vs. patient comparisons. Current Psychological Research and Reviews, 6, 69-78. 
[39] Gebhart G.F., Schmidt R.F. (eds). (2013). Locus of control. Encyclopedia of Pain. Springer, Berlin, Heidelberg

[40] Georgiou, A. \& Bradley, C. (1992). The development of a smoking specific locus of control scale. Psychology and Health, 6, 227-240.

[41] Goldsmith, R. E., Lafferty, B. A., \& Newell, S. J. (2000). The impact of corporate credibility and celebrity credibility on consumer reaction to advertisements and brands. Journal of advertising, 29(3), 43-54

[42] Government

[43] Grinblatt, M., Keloharju, M., \& Linnainmaa, J. (2011). IQ and stock market participation. The Journal of Finance, 66(6), 2121-2164.

[44] Gruen, G., Korte, J. \& Baum, J. (1974). Group measure of locus of control. Developmental Psychology, 10, 683-686.

[45] Gunnarsson, J., \& Wahlund, R. (1997). Household financial strategies in Sweden: An exploratory study. Journal of economic psychology, 18(2-3), 201-233.

[46] Hair Jr., J. F. et al. (1998). Multivariate Data Analysis with Readings. Englewood Cliffs, NJ: Prentice-Hall.

[47] Harrison, T. S. (1994). Mapping Customer Segments for Personal Financial Services. International Journal of Bank Marketing, 12(8), 1725.

[48] Heckman, J. J., Stixrud, J., \& Urzua, S. (2006). The effects of cognitive and noncognitive abilities on labor market outcomes and social behavior. Journal of Labor economics, 24(3), 411-482.

[49] Hill, D. \& Bale, R. (1981). Measuring beliefs about where psychological pain originates and who is responsible for its alleviation. Research with Locus of Control Construct, vol. 1, pp. 281-321. London: Academic Press.

[50] Holt, C. L. (2001). Development and validation of the spiritual and internal health Locus of Control scales. Dissertation Abstracts International: Section B: The Sciences and Engineering, 62, 2536.

[51] https://www.indiabudget.gov.in/economicsurvey/do c/vol1chapter/epreface_vol1.pdf

[52] Inoue, N. (2013). Locus of Control. The Encyclopedia of Cross-Cultural Psychology, 2, 824825.

[53] James, W. H., \& Rotter, J. B. (1958). Partial and $100 \%$ reinforcement under chance and skill conditions. Journal of Experimental Psychology, 55(5), 397.

[54] James, W.H. (1957). Internal versus External Control of Reinforcement as a Basic Variable in
Learning Theory. Unpublished Doctoral Dissertation, Ohio State University.

[55] Jones, J. \& Wuebker, L. (1985). Development and validation of the safety locus of control scale. Perceptual and Motor Skills, 61, 151-161.

[56] Kasilingam, R., \& Sudha, S. (2010). Influence of Locus of Control on Investment Behaviour of Individual Investor. Vidwat: The Indian Journal of Management, 3(1), 17-25

[57] Kormanik, M. B., \& Rocco, T. S. (2009). Internal versus external control of reinforcement: A review of the locus of controlf constifnctiaHun(201Resoliconomic Development Review, 8(4), 463-483.

[58] Labs, S. \& Wurtale, S. (1986). Fetal health locus of control scale: Development and validation. Journal of Consulting and Clinical Psychology, 54, 814819.

[59] Lau, R. \& Ware, J. (1981). Refinements in the measurement of health-specific locus-of-control beliefs. Medical Care, 11, 1147-1158.

[60] Lawler III, E. E. (1973). Motivation in work organizations.

[61] Le Brasseur, R., Blackford, K. \& Whisell, S. (1988). The leford test of tenant locus of control. Environment and Behaviour, 20, 300-319.

[62] Lefcourt, H. (1981). The construction and development of the multidimensionalmultiattributional causality scales. In H. Lefcourt (Ed.), Research with the Locus of Control Construct, vol. 1, pp. 245-261. London: Academic Press.

[63] Lefcourt, H. M. (1966). Internal versus external control of reinforcement: a review. Psychological bulletin, 65(4), 206-220.

[64] Lefcourt, H. M. (1976). Locus of control and the response to aversive events. Canadian Psychological Review/Psychologie Canadienne, 17(3), 202.

[65] Lefcourt, H. M. (1992). Durability and impact of the locus of control construct. Psychological Bulletin, 112(3), 411-414.

[66] Levenson, H. (1974). Activism and powerful other: Distinctions within the concept of internal-external control. Journal of Personality Assessment, 38, 377 383.

[67] Long, R, B. (2007). Development of an instrument measuring oral health Locus of Control: Relationship to general health Locus of Control, oral health care experience, and oral health value. Dissertation Abstracts International Section A: Humanities and Social Sciences, 67, 4466. 
[68] Louden, D. (1978). Internal vs. external control in Asian and West Indian adolescents in Britain. Journal of Adolescence, 1, 283-296.

[69] Marks, L. I. (1998). Deconstructing locus of control: Implications for practitioners. Journal of Counseling \& Development, 76(3), 251-260.

[70] Martin, N. J., Holroyd, K. A. \& Penzien, D. B. (1990). The headache-specific Locus of Control scale: adaptation to recurrent headaches. Headache, 30, 729-734.

[71] McCready, M. \& Long, B. (1985). Locus of control, attitudes toward physical activity, and exercise adherence. Journal of Sports and Exercise Psychology, 7, 346-359.

[72] Miller, P., Lefcourt, H. \& Ware, E. (1983). The construction and development of the Miller Mental Locus of Control Scale. Canadian Journal of Behavioural Science, 15, 266-279.

[73] Mischel, W., Zeiss, R. \& Zeiss, A. (1974). Internalexternal control and persistence: Validation and implications of the Stanford Preschool InternalExternal Scale. Journal of Personality and Social psychology, 29, 265-278.

[74] Montag, I. \& Comrey, A. (1987). Internality and externality as correlates of involvement in fatal driving accidents. Journal of Applied Psychology, 72, 339-343.

[75] NCAER. How households save and invest: Evidence from NCAER household survey; 2011. Retrived on 17 December 2018, from www.nseindia.com

[76] Nicassio, P., Wallston, K., Callahan, L., Herbert, M. \& Pincus, T. (1985). The measurement of helplessness in rheumatoid arthritis: The development of the Arthritis Helplessness Index. Journal of Rheumatology, 12, 462-467.

[77] Nowicki, S. \& Duke, M. (1974 ). A locus of control scale for college as well as non-college adults. Journal of Personality Assessment, 38, 136137.

[78] Nowicki, S. \& Duke, M. (1974b). A preschool and primary school locus of control scale. Developmental Psychology, 10, 874-880.

[79] Nowicki, S. \& Strickland, B. (1973). A locus of control scale for children. Journal of Consulting and Clinical Psychology, 42, 148-1 55.

[80] O'Connell, J. \& Price, J. (1985). Development of a heart disease locus of control scale. Psychological Reports, 56, 159-164.

[81] Ozkan, T. \& Lajunen, T. (2005). Multidimensional traffic Locus of Control scale (T-LOC): Factor structure and relationship to risky driving.
Personality and Individual Differences, 38, 533545.

[82] Parcel, G. \& Mayer, M. (1978). Development of an instrument to measure children's health locus of control. Health Education Monographs, 6, 149-159.

[83] Partridge, C. \& Johnson, M. (1989). Perceived control of recovery from physical disability: Measurement and prediction. British Journal of Clinical Psychology, 28, 53-59.

[84] Paulhus, D. \& Christie, R. (1981). Spheres of control: An interactionist approach to assessment of perceived control. In H. Lefcourt (Ed.), Research with the Locus of ControlConstruct, vol. 1. New York: Academic Press.

[85] Phares, E. J. (1957). Expectancy changes in skill and chance situations. The Journal of Abnormal and Social Psychology, 54(3), 339.

[86] Pompian, M. M. (2012). Behavioral finance and investor types: managing behavior to make better investment decisions. John Wiley \& Sons.

[87] Population2011 - Government of Kerala, India. (2021). Retrieved 20 February 2021, from https://kerala.gov.in/web/guest/population2011

[88] Pruyn, J., van der Borne, H., de Reuver, R., de Boer, M., Ter Pelkwijk, M. \& de Jong, P. (1988). The locus of control scale for cancer patients. TQdscrqt vow Sociale Gexondherdqong, 66, 404408.

[89] Pugh, D. N. (1992). Prisoners and Locus of Control: initial assessments of a specific scale. Psychological Reports, 70, 523-530.

[90] Reid, D. \& Ware, E. (1974). Multidimensionality of internal-external control: Implications for past and future research. Canadian Journal of Behavioural Science, 5, 265-271.

[91] Reid, D. \& Ziegler, M. (1981). The Desired Control Measures and adjustment among the elderly. In H. Lefcourt (Ed.), Research with the Locus of Control Construct, vol. 1, pp. 127-157. New York: Academic Press.

[92] Richaud de Mirzi, M. (1991). A new multidimensional children's locus of control scale. Journal of Psychology, 125, 109-1 18.

[93] Rose, J. \& Medway, F. (1981). Measurement of teachers' beliefs in their control over student outcomes. Journal of Educational Research, 14, 185-190.

[94] Rosenbaum, M. (1980). A schedule for assessing self-control behaviors: Preliminary findings. Behavior therapy, 11(1), 109-121.

[95] Rotter, J. B. (1954). Social learning and clinical psychology. Johnson Reprint Corporation. 
[96] Rotter, J. B. (1966). Generalized expectancies for internal versus external control of reinforcement. Psychological monographs: General and applied, 80(1), 1-28.

[97] Rotter, J. B. (1975). Some problems and misconceptions related to the construct of internal versus external control of reinforcement. Journal of consulting and clinical psychology, 43(1), 56.

[98] Rotter, J. B. (1990). Internal versus external control of reinforcement: A case history of a variable. American psychologist, 45(4), 489 - 493.

[99] Rounds, J. \& Erdahl, P. (1988). Nuclear locus of control scales: Information on development, reliability and validity. Educational and Psychological Measurement, 48, 387-395.

[100] Saboe, K. N., \& Spector, P. E. (2015). Locus of Control. Wiley Encyclopedia of Management, 1-2.

[101] Salamanca, N., de Grip, A., Fouarge, D., \& Montizaan, R. (2020). Locus of control and investment in risky assets. Journal of Economic Behavior \& Organization, 177, 548-568.

[102] Saltzer, E. (1982). The weight locus of control (WLOC) scale: A specific measure for obesity research. Journal of Personality Assessment, 46, 620-628.

[103] Sample Size Calculator by Raosoft, Inc. (2021). Retrieved 20 February 2021, from http://www.raosoft.com/samplesize.html

[104] Schroeder, M. (1985). Development and testing of a scale to measure locus of control prior to and following childbirth. Maternal-Child Care Nursing Journal, 14, 11 1-121.

[105] Semykina, A., \& Linz, S. J. (2007). Gender differences in personality and earnings: Evidence from Russia. Journal of Economic Psychology, 28(3), 387-410.

[106] Shefrin, H. M., \& Thaler, R. H. (1988). The behavioral life-cycle hypothesis. Economic inquiry, 26(4), 609-643.

[107] Simon H.A. (1990) Bounded Rationality. In: Eatwell J., Milgate M., Newman P. (eds) Utility and Probability. The New Palgrave. Palgrave Macmillan, London. https://doi.org/10.1007/978-1349-20568-4_5

[108] Skevington, S. (1990). A standardized scale to measure beliefs about controlling pain. Psychology and Health, 4, 221-232.

[109] Skinner, E. A. (1996). A guide to constructs of control. Journal of personality and social psychology, 71(3), 549.

[110] Slovic, P. (1972). Psychological study of human judgment: Implications for investment decision making. The Journal of Finance, 27(4), 779-799.
[111] Spector, P. (1988). Development of the work locus of control scale. Journal of Occupational Psychology, 61, 335-340.

[112] Stanton, A. (1987). Determinance of adherence to medical regimens by hypertensive patients. Journal of Behavioural Medicine, 10, 377-394.

[113] Stotland, S. \& Zuroff, D. (1990). A new measure of weight locus of control: The Dieting Beliefs Scale. Journal of Personality Assessment, 54, 191-203.

[114] Thaler, R. H., \& Shefrin, H. M. (1981). An economic theory of self-control. Journal of political Economy, 89(2), 392-406.

[115] Tinsley, B. J., \& Holtgrave, D. R. (1989). Maternal health locus of control beliefs, utilization of childhood preventive health services, and infant health. Journal of Developmental and Behavioral Pediatrics, 10(5), 236-241.

[116] Trice, A. (1985). An academic locus of control scale for college students. Perceptual and Motor Skills, 61, 1043-1 046.

[117] Trice, A., Haine, J. \& Elliot, K. (1989). A career locus of control scale for undergraduate students. Perceptual and Motor Skills, 69, 555-561.

[118] Van Raaij, W. F. (2016). Investment Behavior. Understanding Consumer Financial Behavior, 89101. doi:10.1057/9781137544254_7

[119] Van Raaij, W. F. (2016). Saving Behavior. Understanding Consumer Financial Behavior, 3344. doi:10.1057/9781137544254_3

[120] Wallston, K., Wallston, B. \& De Vellis, R. (1978). Development of the multidimensional health locus of control (MHLC) scales. Health Education Monographs, 6, 160-169.

[121] Wallston, K., Wallston, B., Kaplan, E. \& Maides, S. (1976). Development and validation of the Health Locus of Control (HLC) scale. Journal of Consulting and Clinical Psychology, 44, 580-585.

[122] Wäneryd, K. E. (2001). Stock-market psychology: How people value and trade stocks. Edward Elgar Publishing.

[123] Watson, M., Greer, S., Pruyn, J. \& van der Borne, B. (1990). Locus of control and adjustment to cancer. Psychological Reports, 66, 39-48.

[124] Whitehead, J. \& Corbin, C. (1988). Multidimensional scales for measurement of locus of control of reinforcements for physical fitness behaviours. Research Quarter\& for Exercise and Sport, 59, 108-117.

[125] Whitman, L., Desmond, S. \& Price, J. (1987). Development of a depression locus of control scale. Psychological Reports, 60, 583-589. 
[126] Wood, D. \& Letak, J. (1982). A mental health locus of control scale. Personality and Individual Differences, 3, 84-87.

[127] Wood, R., \& Zaichkowsky, J. L. (2004). Attitudes and trading behavior of stock market investors: A segmentation approach. The Journal of Behavioral Finance, 5(3), 170-179.

[128] Worrell, L. \& Timility, L. (1981). The measurement of locus of control among alcoholics. In H. Lefcourt (Ed.), Research with the Locus of Control Construct, vol. 1, pp. 321-333. New York: Academic Press.. 